\title{
"The peculiarities of economic crisis due to COVID-19 pandemic in a developing country: case of Ukraine"
}

\begin{tabular}{|c|c|}
\hline AUTHORS & Bohdan Danylyshyn (D http://orcid.org/0000-0002-4058-1191 \\
\hline ARTICLE INFO & $\begin{array}{l}\text { Bohdan Danylyshyn (2020). The peculiarities of economic crisis due to COVID- } \\
19 \text { pandemic in a developing country: case of Ukraine. Problems and } \\
\text { Perspectives in Management, 18(2), 13-22. doi:10.21511/ppm.18(2).2020.02 }\end{array}$ \\
\hline DOI & http://dx.doi.org/10.21511/ppm.18(2).2020.02 \\
\hline RELEASED ON & Friday, 10 April 2020 \\
\hline RECEIVED ON & Monday, 16 March 2020 \\
\hline \multirow[t]{2}{*}{ ACCEPTED ON } & Thursday, 09 April 2020 \\
\hline & $(\mathrm{cc}) \mathrm{EY}_{\mathrm{EY}}$ \\
\hline LICENSE & $\begin{array}{l}\text { This work is licensed under a Creative Commons Attribution } 4.0 \text { International } \\
\text { License }\end{array}$ \\
\hline JOURNAL & "Problems and Perspectives in Management" \\
\hline ISSN PRINT & $1727-7051$ \\
\hline ISSN ONLINE & $1810-5467$ \\
\hline PUBLISHER & LLC “Consulting Publishing Company "Business Perspectives" \\
\hline FOUNDER & LLC “Consulting Publishing Company "Business Perspectives" \\
\hline & $\begin{array}{l}= \pm: \\
= \pm:-\end{array}$ \\
\hline NUMBER OF REFERENCES & NUMBER OF FIGURES \\
\hline 32 & 0 \\
\hline
\end{tabular}

(c) The author(s) 2021. This publication is an open access article. 


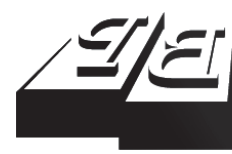

\section{BUSINESS PERSPECTIVES}

LLC "CPC "Business Perspectives" Hryhorii Skovoroda lane, 10, Sumy, 40022, Ukraine www.businessperspectives.org

Received on: $16^{\text {th }}$ of March, 2020 Accepted on: $9^{\text {th }}$ of April, 2020 Published on: $10^{\text {th }}$ of April, 2020

๑) Bohdan Danylyshyn, 2020

Bohdan Danylyshyn, Doctor of Economics, Academician of NSA of Ukraine, Chair of Department of Regional Studies and Tourism, Kyiv National Economic University named after Vadym Hetman, Ukraine.

\begin{abstract}
At the beginning of 2020, the world faced the most frightening threat to the population's health - COVID-19 pandemic. For this reason, the international institutions, governments of countries and various organizations are forced to use unprecedented restrictive measures in many spheres of activity. As a result, the economies of the countries all over the world are significantly affected and are on the verge of crisis. This paper presents examples of economic consequences of COVID-19 pandemic for different countries of the world and analyzes still few scientific works, which study the influence of pandemic on their economies. The article generalizes the legislative and anti-crisis measures of the Ukrainian Government, as well as the National Bank of Ukraine and other state authorities. It is evidenced that at the end of 2019 and the beginning of 2020, Ukraine witnessed a significant decrease in GDP growth rate, reduction of industrial production and electricity production. The financial indicators also underwent significant losses, particularly the unemployment rate increased as thousands and thousands of labor migrants have returned to Ukraine from European and other countries. The article proves the inconsistency and unprofessionalism of such restrictive and regulatory measures. Finally, the necessity is substantiated to combine the methods of market economy and state regulation. The compulsory steps are offered, which would minimize the losses of the state and its population during this economic crisis.
\end{abstract}

Keywords

JEL Classification

\section{INTRODUCTION}

In January 2020, World Health Organization (WHO) declared COVID-19 a world health emergency. The epidemic propagation on a global scale and unprecedented protection means, which the countries of the world use to prevent the propagation of the dangerous disease COVID-19, will undoubtedly have the consequences for the breaking of economic activity and reduction of aggregate demand on a global scale. Global nature of the restrictive measures will affect both the production activity of the sectors and corporations, which are included in the global value-added chains, and the common business entities, whose production interests did not move beyond the country. Turbulence in world financial markets naturally strengthened in response to tough restrictive measures and the effects connected with global trade war. The society considers COVID-19 a bigger threat for the economy rather than their health, and there is no concern for economic saving measures announced by the governments (Oliver, 2020; Semuels, 2020). In the countries with economic problems, which took place before the worldwide COVID-19 epidemic (e.g., in Ukraine), the situation can be worse than in many other countries. 
This paper aims to generalize the statistics and the scientists' and experts' opinions about the economic crisis in Ukraine, caused by the consequences of COVID-19 epidemic and struggling with it, and the formation of the propositions on minimizing its possible negative effects.

\section{LITERATURE REVIEW}

COVID-19 epidemic propagates across the planet rigidly and at a high rate. Today many are concerned not only for the people's health state but also for the state of the economy. At the World Economic Forum website, it is noted that COVID-19 has the potential to take lives, undermine economies, overwhelm health systems, deplete the value of assets, and trigger lasting geopolitical change (World Economic Forum, n.d.). Nowadays, one talks about the next world economic crisis.

One should note that in recent years, the issues on economic crises were quite often studied in the scientific literature, which got significant impetus after the 2008-2009 financial crises.

So, Tatliyer (2017) analyzes the reasons for such large financial crisis. Supposedly, it is the formation of a housing bubble and the ensuing subprime mortgage crisis in the US economy. Bu the main reasons are caused by systemic problems in the world economy, namely failure of transforming economies from extensive-production to intensive-production, the rise of the neoliberalism, ensuing financialization of the world economy, and global instabilities witnessed in the neoliberal era.

For example, Frankel and Saravelos (2012) did an interesting study on whether some indicators of the country's state can help explain the domestic 2008-2009 financial crises. They analyzed a significant number of scientific literatures on early warning indicators. Their review shows that the central bank reserves and past changes in the real exchange rate were the main indicators that appeared to be the most useful for explaining the possibility of a crisis in different countries. To measure the crisis level, the researchers offer to use the following indicators: drops in GDP and industrial production, currency depreciation, stock market performance, reserve losses, and participation in an IMF program.
Hodgson (2009) finds whether the economic crisis can create favorable conditions for reforming and reviving the economy itself, and the reason why the governments did not heed the warnings on possible financial crash. He thinks that it is partially connected with the triumph of individualistic market ideology and partially with exaggerated roles of modeling and quantitative definition.

Another study (Feldkircher, 2014) defines the macroeconomic and financial conditions, which help explain the reaction of the real economy of a certain country to the global financial crisis. So, the pre-crisis growth of loans in the real economy by $1 \%$ means increasing the losses of real production volume by $0.2 \%$. One cannot fail to note that the government, e.g., Ukrainian, should pay attention to it. Also, he concludes that the rapid growth of real GDP, in parallel with significant growth of loans, significantly strengthens the consequences of the crisis for the real economy. At the same time, the accumulation of international reserves alleviated an adverse impact of financial stress on the real economy, particularly when there is sufficient internal financing at the account of loans.

Luchtenberg and $\mathrm{Vu}$ (2015) note that, unlike the previous crises, contagion following the 2008 global financial crisis is not only limited by developing markets but also the developed countries of the world suffer from it, first of all, due to trade structure, interest rates, inflation rates, industrial production, and regional effects, and investors' risk aversion.

One more example concerns the study on the effect of the 2008-2009 global economic crises on the Chinese society, namely the scales of unemployment in the cities (Cai \& Chan, 2009). It is stated that the measures for further integration of village and city labor markets and decrease of natural unemployment level finally are more profitable than the short-term interventions for adjusting cyclical unemployment, which appears because of the global economic crisis and recession. 
One can find quite many similar and more largescale researchers like Dullien, Kotte, Márquez, and Priewe (2010), Verick and Islam (2010). It is clear that the 2008-2009 financial crises led to irreparable consequences practically for the economies of all countries of the world, and these consequences stretched back over many years, and this crisis had cyclical nature.

This time one deals with not cyclical but artificial crisis when the government's restrictive measures cause it. Nevertheless, there are some parallels. The paper analyzed several variants of developments and their end - financial crisis. As a result, "Delayed shipments and production schedules create financial problems for companies with heavy debts, especially in the United States. The decline in global equity markets and flight from risk-investors selling assets such as high-yield bonds and volatile stocks-exposes investors who have underpriced risk. Concern about counterparty risk accelerates the decline and dries up liquidity in financial markets. Central banks scramble to manage the problem. Financial markets-and the global economy-recover after a V-shaped recession" (Bachman, 2020).

Tooze (2020) attempts to answer the question, "Is now the situation not worse than in 2008?"

The leading economic institutions monitor the situation in the world economy and in the economies of countries of the world and actually begin to adjust the forecasts of their dynamics online.

According to IIF data (as of the end of March 2020), the USA, Eurozone, and Japan are already in the state of economic downturn, which will last at best until the middle of the year. To understand the scale of negative tendencies, one should note that according to IMF data for $2019,15.1 \%$ of world GDP was for the USA, near $11 \%$ - Eurozone, near 4\% - Japan (International Monetary Fund, n.d.). It means the economic downturn will be in the countries giving $30 \%$ of world GDP. Besides, it is also necessary to take China into account, whose industrial production in January-February of the current year decreased by $13.5 \%$, which will obligatorily affect its GDP. For 2020, IIF forecasts the decrease of GDP of the Eurozone countries by $2.8 \%$, Japan - by $1.5 \%$. China will not be able to support the world economy as well - according to the forecast, GDP of this country will increase by $3.5 \%$ (after the increase by $6.1 \%$ in 2019 , which was called the slowest growth of the Chinese economy from 1990). Key assumption of this forecast is the expected recovery of the economies in the second half of 2020. It means the recovery of the world economy in the second half can be expected only in case COVID-19 pandemic will decline by the summer. However, if the pandemic will take too long, then much more pessimistic forecasts can be realized.

Yet today JP Morgan Bank sharply decreased its forecast on the growth of the US economy, having forecasted the GDP decrease by $3.7 \%$ in the second quarter of 2020 (to first quarter). If this forecast comes true, then the quarterly decrease will be even larger than in the fourth quarter of 2008, at the peak of then-world economic crisis. The rating agency S\&P forecasts the global recession in 2020 (S\&P Global, n.d.).

The evaluations at the beginning of the epidemic state that if the virus becomes a global pandemic, then the majority of large economies will lose at least $2.4 \%$ of its GDP during 2020. The economists already decrease the forecasts for world economic growth for 2020 from 3.0 to $2.4 \%$. If world GDP in 2019 was evaluated as nearly USD 86.6 trillion, it means that the decrease only by $0.4 \%$ is nearly 3.5 trillion. However, it is necessary to keep in mind that the forecasts were made before COVID-19 became a global pandemic, and before making largescale restrictions on social contacts among people. Since then, the world stock markets underwent a significant downturn (Duffin, 2020).

Segal and Gerstel (2020) state that the evaluations of the global impact of the pandemic are different: at the beginning of March 2020, Organization for Economic Cooperation and Development (OECD) forecasted that COVID-19 would decrease the growth of world GDP by half of percentage point till 2020 (from 2.9 to 2.4\%) (OECD Library, 2020), and Bloomberg Economics warns that full increase of GDP can fall to zero in the worst scenario of the pandemic (Orlik, Rush, Maeva, \& Hong, 2020). Institute of International Finance (IIF) (n.d.) constantly makes detailed forecasts. So, at the end of March, it decreased its forecast 
on the world economic growth in 2020 to $0.4 \%$. Obviously, the situation in the world economy becomes worse every day and there takes place active revision of the forecasts - only two weeks earlier this very IIF decreased the forecast on world GDP growth from 2.6 to $1.6 \%$, but from that time the shock connected with COVID-19, already managed to transform itself into stopped global capital markets.

Sharp worsening is expected in the second quarter of 2020. However, the forecasts for the results of the first quarter are not at all optimistic. It is expected that the US GDP in the first quarter will decrease by $0.2 \%$ (to the fourth quarter of 2019). According to the results of the second quarter, the US economy can find itself in recession (from the common viewpoint, recession is a decrease of GDP during two successive quarters). American stock indexes have already lost all growth rates, which took place during D. Trump's presidency. The markets weakly react to two emergency decreases of FRS rate, to announced, started financial injections (during the last three weeks of March - USD 510 billion, and announced measures are USD 1.5 trillion), and to other measures of the economy's financial support. The first bad data came from the US labor market - the number of appeals for unemployment allowances increased from 215 thousand to 280 thousand. It means in May, the unemployment rate in the USA can be 7-8\% (Institute of International Finance, n.d.).

Gormsen and Koijen (2020) use the data from the aggregate equity market and dividend futures to quantify how investors' expectations about economic growth across horizons evolve in response to the coronavirus outbreak and subsequent policy responses. Their forecast as of March 25 on the annual dividends rise decreased by $28 \%$ in the USA and by $22 \%$ in the EU, and the forecast on GDP growth decreased by $2.2 \%$ in the USA and by $2.8 \%$ in the EU.

The United Nations Organization forecasts that foreign direct investment flows can decrease from 5 to 15 percent to the lowest level after the 20082009 global financial crises (UNCTAD, 2020).

International Monetary Fund also monitors the situation connected with COVID-19 pan- demic, in 193 countries (economies) of the world (International Monetary Fund, n.d.). On its website, it is noted that "The tracker focuses on discretionary actions that supplement existing social safety nets and insurance mechanisms". The information is not full enough, as it is formed based on the data published and available on the Internet. However, it gives an idea of the scale of the unfolding crisis and characterizes the extent of concern of the governments of the vast majority of countries of the world. So far, the governments announced mainly inconsistent reactions to the epidemic, peculiar to each country. As for the consistent actions, on March 6, the ministers of finance of G20 and central bank governors pledged to take the respective fiscal and monetary measures, but did not undertake certain obligations. International Monetary Fund and World Bank announced the availability of financing of USD 50 billion and USD 12 billion, respectively, to support low income and emerging market economies (Segal \& Gerstel, 2020).

Various institutions constantly prepare the analytical and statistical reports on the development of epidemic and its possible consequences (Congressional Research Service, 2020; OECD Library, 2020; Duffin, 2020).

Thus, it is necessary to keep in mind all the complexity and emergency of the situation in the world economy. Directly in Ukraine it is aggravated by the whole range of problems even before COVID-19 pandemic.

In the fourth quarter of 2019, Ukraine witnessed a sharp slowdown of GDP growth. If in the second quarter, GDP increased by $4.6 \%$, in the third quarter - by $4.1 \%$, then in the fourth quarter - only by $1.5 \%$. Moreover, according to the Ministry for Development of Economy, Trade and Agriculture of Ukraine, in January, GDP decreased by $0.5 \%$ (Ministry for Development of Economy, Trade and Agriculture of Ukraine, n.d.). For 2019, industrial production in Ukraine decreased by $1.8 \%$. It decreased at the end of 2019 at a particularly rapid pace - by $7.5 \%$ in November, by $7.7 \%$ in December. In 2020, the decrease in industrial production continued - in January, it decreased by $5.1 \%$. 
According to the State Statistics Service of Ukraine (State Statistics Service of Ukraine, n.d.), the trade balance deficit in 2019 was USD 12.2 billion, which is $7 \%$ more than in 2018. In November 2019, the unemployment increased (compared to October) by $11.5 \%$, in December 2019 (compared to November) - by 17\%. The steel production in Ukraine in 2019 decreased, compared to 2018 , by $1.3 \%$, cast iron production - by $2.5 \%$. In 2020 , the decrease in the iron-andsteel industry, basic industry of Ukraine's economy, continued. So, steel production in January decreased by $5.1 \%$, cast iron production - by 2.7\% (compared to January 2019). In February, according to "Ukrmetalurgprom" association data, steel production decreased by $8.3 \%$, cast iron production - by $7.5 \%$ (compared to January) (Ukrmetalurgprom, n.d.). Electricity production decreased by $4.9 \%$ in 2019 , compared to 2018 .

Problems in the real sector of Ukraine's economy led to the problems for state finance, and the slowdown of tax revenues was found there. The loans begin to play a larger role among the sources of funds of public administration sector, which includes the funds of state and local budgets, and extrabudgetary social insurance funds. These loans are begun to be used not only to refinance the existing debt but also to finance current expenditures. The share of loans in the total amount of funds that public administration sector obtained from taxes, social contributions, and loans increases during 5 successive years. In January 2020, an annualized share was already $25 \%$.

2020 budget execution is performed with a lag from planned indicators. In January, the revenues of general state budget fund were executed only to $75.5 \%$, in February - to $93.7 \%$. In March, the state budget underfulfilment only exacerbated: during March 1-20, the execution of the plan of revenues by the tax authorities was $50.6 \%$, customs $-56.9 \%$. The plans on state property privatization are also not executed - in January-March, the budget received UAH 202 million, which is by a third lower than the planned revenues.

At the same time, the expenditures on labor wages and social provision, which are the protected budget items, continue to increase. In particular, the expenditures on social provision increased in
January-February more than 1.5 times (from UAH 30 to UAH 49.5 billion), compared to the same period of last year, which is due to the change in the mechanism for financing a range of social payments in the direction of its financing directly from the central-level budget.

At the same time, according to the plan of payment on external debt to non-residents in AprilDecember 2020, the government of Ukraine and local self-government authorities should pay USD 5.8 billion, to state companies and banks - nearly USD 0.7 billion. Besides, in April-December 2020, the payments on state treasury bond of Ukraine, nominated in foreign currency, will be USD 2.4 billion (both to residents and non-residents), on those in UAH, which are owned by non-residents - UAH 21 billion (loan repayment and service). One should note that in Ukraine, as of March 18, 2020 , the amount of state treasury bonds, which are owned by physical persons, is only UAH 9 billion ( $0.2 \%$ of GDP, or nearly USD 300 million). The overwhelming majority of these state treasury bonds (67\%) are nominated in foreign currency.

It is against this background that one observed the decrease of inflation rate lower than the NBU's target range, and the producer's prices - lower than zero, which shows the features of full stagnation in the sector of goods and services production and the noticeable decrease of the volume of its activity. Instead, the sectors, connected with providing the intermediary financial and business services, increase at a fast pace. Only the profit of commercial banks, according to 2019 results, was UAH 60 billion, having increased almost three times, compared with last year.

The huge money amounts (for Ukraine), which the real economy does not receive, were accumulated in the banking system. To suppress the excessive tension of "odd" UAH supply, the NBU extended the operations with deposit certificates three times - to UAH 200 billion. In better times, the volume of loans for the economy was $80 \%$ of GDP, now it does not gain at least $25 \%$ of GDP, and if one removes the non-performing loans - it will not be even $15 \%$ of GDP. Now real producers cannot compete for loan resources of internal financial market at the rates, offered by deposit corporations. At the same time, the relative amount of 
NBU and STB deposit certificates - passive directions of fund injections - is already $24 \%$ of GDP, thus, surpassing the volume of loan resource, given by deposit corporations to the real sector of the economy.

This situation is fraught with the effect of largescale outflow of capital from the country, where there are no reliable objects for its investment, particularly taking into account its instability at the global capital markets.

In the policy on counteracting COVID-19, published on March 15, International Monetary Fund recommends the central banks to take measures to support the demand by simplifying the financial conditions, ensuring the continuity of loan support of the economy and liquidity at the domestic and international financial markets.

As for Ukraine, the situation is quite adequately illustrated in the following quotation: "The Ukrainian government must act fast to avoid a repeat of the 15\% GDP contraction the country experienced in 2009. Encouragingly, it can count on some relatively sound fundamentals. The banking sector is in much better shape than it was in 2009; the level of government debt is relatively low; and the National Bank of Ukraine has ample reserves. Initial steps have been encouraging, suggesting an awareness of the need to stimulate the economy and ease the burden on businesses. Nevertheless, the sheer scale of the unfolding global crisis makes significant economic difficulties inevitable for Ukraine in the near future" (Gorodnichenko, 2020). He asks a reasonable question: "What can policymakers do to sail through this storm?"

In the mentioned resource of International Monetary Fund, one mentions the creation of stabilization fund for struggling with the crisis consequences, which the government of the country proposed, with a size of nearly UAH 115 billion. However, more than three weeks have already passed (it is the unacceptably long time in the conditions of pandemic), but there is no fund.

In terms of fiscal policy as of March 25, 2020, such Ukraine's initiatives are presented on the website: "To support households, the government is planning: (1) a one-off pension increase to low-income pensioners of UAH 1,000; (2) an earlier-than-planned indexation adjustment of pensions in 2020; (3) a moratorium on penalties and disconnection of consumers who are late on utility payments; (4) reduced eligibility criteria for household utility subsidies; (5) an additional allowance of 150-200 percent of wage for medical professionals working with people with COVID-19. Medicines and medical devices used to prevent or combat COVID-19 have been exempt from import duties and VAT. Additionally: (1) penalties for certain tax legislation violations have been canceled for the period March 1 - May 31, 2020; (2) a moratorium on audits and inspections has been introduced for the period March 18 - May 31, 2020; (3) the deadline for filing annual income and asset declarations has been extended to July 1, 2020; (4) rent on land is not accrued and paid for the period March 1 - April 30, 2020; (5) non-residential real estate owned by individuals or legal persons is not subject to real estate tax for the period March 1 - April 30, 2020; (6) payment of Single Social Contribution for several categories of payers has been canceled and penalties for late or incomplete payment and late filing has been abolished for the period March 1 - April 30, 2020" (International Monetary Fund, n.d.).

In terms of monetary and macro-financial policy, the following measures are taken and planned: "The National Bank of Ukraine has changed the operational design of monetary policy. The frequency of liquidity tenders has been doubled, two-week certificates of deposit have become one-week certificates, and short-term refinancing loans with a maximum maturity of 14 days are now issued for a period of up to one month. The NBU has also introduced long-term refinancing instrument (up to 5 years). The introduction of capital buffers-including the capital conservation buffer and the systemic buffer-will be delayed. However, banks must meet the minimum capital and regulatory capital requirements. Onsite inspections and stress testing of the banks have been delayed. Banks are also invited to temporarily refrain from distributing profits through dividend payments until at least July 2020, ensuring that financial institutions have an additional margin of safety. NBU has adopted a regulation that facilitates restructuring of loans to borrowers facing financial difficulties due to the impact of COVID-19. Penalties on clients not servicing loans 
during the period from March 1 to April 30 should not apply if there are reasonable grounds. The NBU has been active on the foreign exchange market to smooth volatility. Finally, the NBU has announced that it may, should situation require: (1) reduce reserve requirement ratios for FX deposits; (2) temporarily decrease the minimum LCR; (3) announce unscheduled liquidity assistance tenders; and (4) expand the list of eligible collateral for emergency liquidity assistance loans".

Unfortunately, one should point once again to the fact that these initiatives are not fully implemented, it is done slowly, and they are obviously insufficient.

\section{DISCUSSION}

The mentioned examples show that the government institutions wish to struggle with crisis by way of rigid intervention in the economic processes.

Keynes $(1930,1936,1963)$ notes the possibilities of combining the methods of the market economy with an active part of the state in times of crisis, avoiding directive planning. Keynes placed the issues of demand, savings, and consumption at the forefront. If demand is at an insufficient level, it will lead to depression in the economy and unemployment growth. In the near future, millions of citizens, left without wages and other income, having understood the aggravation of the situation, will reduce the demand significantly. The destructive chain will be launched - reduction of demand will aggravate the economic downturn, which will lead to unemployment growth, and the latter will lead to reduced demand. Everything can move forward on this downward spiral.

According to Keynes, even with part-time employment, the economy can achieve the state, which requires such a volume of investment that will compensate the volume of "reduced" consumer demand (because of unemployment growth, uncertainty about the future and, as a result, increased inclination of the population towards reducing the expenditures). The state measures on the demand stimulation can ensure this volume, although indirectly.
Keynes did not share the optimism of the representatives of Libertarian and Classic schools of economic thought on the fact that the market will ensure the demand recovery. He stated that if the economy working on laissez-faire principles (self-regulation, which copes with a crisis without the state's participation) does no cope, the state's proactive participation is necessary using the methods of active demand stimulation.

Keynes reasonably thought that the problem lies not in the fact that the market economy uses the factors in its disposal insufficiently, but in that it uses not all the factors available. So the state, by stimulating the demand and employment, should help to use them. Naturally, the methods that Keynes proposes are not ideal. For example, because its model is static - studies the process on a relatively short-term perspective of several years. Also, Keynes did not fully take into account the business cycles.

Still, it is possible to answer these questions as well, which show the expediency of Ukraine using the Keynes' theory in the conditions of rigid aggravation of the economic situation rather than support it. First, Keynes' theory appeared as a response to the Great Depression. Nowadays, the dynamic of a range of indicators in the world economy shows that the current crisis can be no less dramatic. Consequently, the Keynesian measures will be relevant. Second, the threat to Ukraine's economy is so large that there is no point in making the longterm strategic plans - it is necessary to save the economy right now, give people the possibility to keep their income. Third, nowadays, serious countercyclical measures will be necessary.

It is also worth noting that even in the most prosperous times, even among the economically most liberal countries, there were not those where the role of the state was limited only by the protection of boundaries and police functions.

One should note that the situation in the Ukrainian economy was caused by excessively rigid parameters of macroeconomic policy, within the frameworks of which the Ukrainian economy was developing during several last years.

Given the state of emergency in the economy and quarantine measures, potential losses of reve- 
nues to the state budget because of the shortfall of income tax, individual income tax, other taxes and fees, the situation with the budget execution can worsen further, which causes the necessity of analyzing several alternative scenarios of deficit financing.

Taking into account that very significant financial resources are in the extra-bank turnover of Ukraine due to the probable outflow of funds from bank deposits and the inflow of currency assets connected with the return of labor migrants to Ukraine due to COVID-19 epidemic, it can be reasonable to expand the instruments for attracting the currency assets of the population to finance the budget needs.

Admittedly, the Ministry of Finance performed the risky policy on the massive attraction of non-residents to state treasury bonds, not assuming that crises happen in the world economy. However, nowadays, considering the international experience of separate EU countries, the attraction of the volume of the population's currency assets in state treasury bonds, even at the amount of $5 \%$ of GDP, can be evaluated in a sum of more than USD 7 billion. However, one should keep in mind that the acting procedure of state treasury bonds sales for the population is burdened by high transaction and time expenditures (connected with paying for intermediary banks' services when purchasing the state treasury bonds), which makes such an operation attractive only with the amount of purchase of UAH 500 thousand and more.

The indicator of real monetary conditions rigidity (as a combination of the effects of interest rate and changes in the exchange rate) exceeds the same indicator in the neighboring European countries by 10 and more percentage points. Ukraine also witnesses such an excessive rigidity of monetary conditions beginning from the second half of 2018 .

The fiscal policy was also untenable. In Ukraine, the fiscal balance, if calculated without the debt servicing costs, is surplus beginning from 2015. From this year, the real economy has a constant structural shock due to reduced state demand and should be restructuring in the conditions of rigid monetary policy and low domestic effective demand.

One should note that the NBU's actions on changing the interest rate slow down the economic growth for several years already. The reason for this is that the "Austrian" school of economic thought, supported by the Ukrainian proponents of the priority of inflation control over any other goals, also talks about the critical role of entrepreneurs in this process.

The separate aspect of the economic policy failures is the NBU's policy on the exchange rate and formation of domestic reserves. Instead of reducing the excessive demand for UAH financial assets (caused by uncovered parity of interest rates of the external and domestic capital markets) by reducing the rate, the NBU chose another way - it simply allowed the UAH to strengthen (this is how the transmission channel of the exchange rate works within the frameworks of inflation targeting regime). As a result, the state budget borrows at the rates, which exceeds the annual rates of its revenues, the exporters bear losses because of decrease UAH revenue, the real sector received less than due credit resources, and the country received less than due revenues in currency reserves, which still do not comply with the norm of IMF composite criterion by $20 \%$.

\section{CONCLUSION AND RECOMMENDATIONS}

The analysis showed that Ukraine should not make the economic experiments in the libertarianism style and "Austrian schools of economic thought", but it is necessary to return to time-tested and well-established in times of crisis economic practices. One should revisit the ideas of the neo-Keynesian theory. Nowadays, in times of crisis, it is necessary to use the ideas on stimulating the growth within the frameworks of industrial protectionist policy. It is necessary to urgently prepare the realistic government program directed towards the reindustrialization of Ukraine's economy, based on the fact that it will be impossible to prevent the serious recession without emergency support measures (as well as work with IMF taking into account this fact). 
It is necessary to launch the demand stimulation programs, if possible, with their focus on purchasing the products from a domestic producer. This will enable to decrease the negative impact of the crisis on the citizens' welfare, will prevent the decrease of business activity, will create the conditions for the development of Ukrainian producers and will reduce the dependence on uncritical import. Also, it is essential to make adjustments to the models that macroeconomic regulators use to assess the effects of their policy on the economic growth rates and social welfare in the country, considering structural problems. The complex of measures should be developed in order to keep the economic potential of the country, first of all, its industrial core.

The state should ensure the possibility of real investment projects financing, directed towards increasing the economy's competitiveness and expansion of its domestic market, use the expansion of the instruments of state guarantees. Moreover, cooperation with international official creditors should be enhanced based on fundamentally different foundations of domestic macroeconomic policy formation and its focus on country's economic potential growth.

One can hope that despite the massive scale of consequences of the crisis caused by COVID-19 pandemic, they will not be as long-lasting as after 2009.

\section{REFERENCES}

1. Bachman, D. (2020, March 3). The economic impact of COVID-19 (novel coronavirus). Deloitte. Retrieved from https://www2. deloitte.com/us/en/insights/economy/covid-19/economic-impactcovid-19.html

2. Cai, F., \& Chan, K. W. (2009). The Global Economic Crisis and Unemployment in China. Eurasian Geography and Economics, 50(5), 513-531. Retrieved from https:// www.researchgate.net/publication/228651428_The_Global_Economic_Crisis_and_Unemployment_in_China

3. Congressional Research Service (2020). Global Economic Effects of COVID-19. Retrieved from https:// fas.org/sgp/crs/row/R46270.pdf

4. Duffin, E. (2020, April 3). Impact of the coronavirus pandemic on the global economy - Statistics \& Facts. Statista. Retrieved from https:// www.statista.com/topics/6139/ covid-19-impact-on-the-globaleconomy/

5. Dullien, S., Kotte, D. J., Márquez, A., \& Priewe, J. (Eds.) (2010). The Financial and Economic Crisis of 2008-2009 and Developing Countries. UNCTAD. Retrieved from https://unctad.org/en/Docs/ gdsmdp20101_en.pdf
6. Feldkircher, M. (2014). The determinants of vulnerability to the global financial crisis 2008 to 2009: Credit growth and other sources of risk. Journal of International Money and Finance, 43, 1949. Retrieved from https://www. sciencedirect.com/science/article/ pii/S0261560613001770

7. Frankel, J., \& Saravelos, G. (2012). Can leading indicators assess country vulnerability? Evidence from the 2008-09 global financial crisis. Journal of International Economics, 87(2), 216-231. Retrieved from https://www.sciencedirect. com/science/article/abs/pii/ S0022199611001735?via\%3Dihub

8. Gormsen, N. J., \& Koijen, R. S. J. (2020). Coronavirus: Impact on Stock Prices and Growth Expectations. University of Chicago, Becker Friedman Institute for Economics Working Paper No. 2020-22. Retrieved from https:// papers.ssrn.com/sol3/papers. cfm?abstract_id=3555917

9. Gorodnichenko, Y. (2020, March 19). Saving Ukraine's economy from the coronavirus crash. Retrieved from https://atlanticcouncil. org/blogs/ukrainealert/savingukraines-economy-from-thecoronavirus-crash/
10. Hodgson, G. M. (2009). The Great Crash of 2008 and the Reform of Economics. Cambridge Journal of Economics, 33(6), 1205-1221. http://dx.doi.org/10.1093/cje/ bep050. Retrieved from https:// papers.ssrn.com/sol3/papers. cfm?abstract_id $=1500863$

11. Institute of International Finance (n.d.). Official website. Retrieved from https://www.iif.com/

12. International Monetary Fund (n.d.). IMF Data. Retrieved from https://www.imf.org/en/data

13. International Monetary Fund (n.d.). Policy Responses to COVID-19. Retrieved from https:// www.imf.org/en/Topics/imf-andcovid19/Policy-Responses-toCOVID-19\#U

14. Keynes, J. M. (1930). A Treatise on Money.

15. Keynes, J. M. (1936). The General Theory of Employment, Interest and Money.

16. Keynes, J. M. (1963). Economic Possibilities for our Grandchildren. In Essays in Persuasion (pp. 358-373). N.Y.: W. W. Norton \& Co.

17. Luchtenberg, K. F., \& Vu, Q. V. (2015). The 2008 financial crisis: Stock market contagion 
and its determinants. Research in International Business and Finance, 33, 178-203. Retrieved from https://www.sciencedirect. com/science/article/abs/pii/ S0275531914000518?via\%3Dihub

18. Ministry for Development of Economy, Trade and Agriculture of Ukraine (n.d.). Official website. Retrieved from https://www. me.gov.ua/?lang=en-GB

19. OECD Library (2020, March 2). OECD Economic Outlook, Interim Report. Retrieved from https:// read.oecd-ilibrary.org/economics/oecd-economic-outlook/ volume-2019/issue-2_7969896ben\#page 1

20. OECD Library (2020, March 2). OECD Economic Outlook, Interim Report. Retrieved from https:// www.oecd.org/berlin/publikationen/Interim-Economic-Assessment-2-March-2020.pdf

21. Oliver, L. (2020, March 18). Most people see COVID-19 as an economic crisis first, health risk second, survey finds. World Economic Forum. Retrieved from https://www. weforum.org/agenda/2020/03/ covid-19-public-perception-economic-health-crisis-coronaviruspandemic-ipsos/
22. Orlik, T., Rush, J., Maeva, C., \& Hong, J. (2020, March 6). Coronavirus Could Cost the Global Economy \$2.7 Trillion. Here's How. Bloomberg. Retrieved from https://www.bloomberg.com/ graphics/2020-coronavirus-pandemic-global-economic-risk/

23. S\&P Global (n.d.). Ratings. Retrieved from https://www.spglobal. com/ratings/en/

24. Segal, S., \& Gerstel, D. (2020, March 10). The Global Economic Impacts of COVID-19. Center for Strategic and International Studies. Retrieved from https://www.csis. org/analysis/global-economicimpacts-covid-19

25. Semuels, A. (2020, March 18). As COVID-19 Crashes the Economy, Workers and Business Owners Wonder If Anything Can Save Them From Financial Ruin. TIME. Retrieved from https://time. com/5805526/coronavirus-economy-layoffs/

26. State Statistics Service of Ukraine (n.d.). Official website. Retrieved from http://www.ukrstat.gov.ua/

27. Tatlyer, M. (2017). The 20082009 Financial Crisis in Historical Context. In Hacioğlu Ü., Dinçer H. (Eds.), Global Financial
Crisis and Its Ramifications on Capital Markets. Contributions to Economics (pp. 3-17). Springer, Cham. Retrieved from https://rd.springer.com/chapter/10.1007/978-3-319-47021-4_1

28. Tooze, A. (2020, March 18). Is the Coronavirus Crash Worse Than the 2008 Financial Crisis? FP. Retrieved from https://foreignpolicy. com/2020/03/18/coronaviruseconomic-crash-2008-financialcrisis-worse/

29. Ukrmetalurgprom (n.d.). Official website. Retrieved from http:// www.ukrmetprom.org/

30. UNCTAD (2020, March 8). Coronavirus could shrink global FDI by $5 \%$ to $15 \%$. Retrieved from https:// unctad.org/en/pages/newsdetails. aspx? OriginalVersionID $=2299$

31. Verick, S., \& Islam, I. (2010). The Great Recession of 2008-2009: Causes, Consequences and Policy Responses (IZA Discussion Paper No. 4934). Retrieved from http:// ftp.iza.org/dp4934.pdf

32. World Economic Forum (n.d.). COVID-19. Retrieved from https:// intelligence.weforum.org/topics/ a1G0X000006O6EHUA0?tab=pu blications 